\title{
The Effect of Pedagogical Competence and Work Environment toward Elementary School Teachers Performance
}

\author{
Super Boy Marsen ${ }^{1}$, Heru Santosa ${ }^{2}$, Siti Rochanah ${ }^{3}$ \\ DOI: 10.35445/alishlah.v13i1. 563
}

\begin{tabular}{l}
\hline Article Info \\
\hline Keywords: \\
Pedagogical Competence \\
Work Environment \\
Teacher Performance
\end{tabular}

\section{Abstract}

This research aimed to investigate the effect of pedagogic competence and work environment on the performance of elementary school teachers at the Kuantan Singingi District. Methodology in This study uses a quantitative approach-with a path analysis model. The participants of this study were 103 elementary teachers in Kuantan Singingi District, Singingi Hilir District. The research instrument was a closed questionnaire on the google form application. The questionnaire used a five-point Likert scale. Hypothesis testing is obtained from the t-test and F-test. The results show that there were several conclusions, namely: 1) pedagogical competence has a positive and significant effect on elementary school teachers performance in Singingi Hilir District, the increasing of pedagogical competence of the teachers could improve their performance, 2) The working environment has a positive and significant impact on the performance of teachers in the District Elementary School Singingi Hilir, where a good work environment would improve teacher performance. 3) pedagogical competence and work environment affected the performance of public elementary school teachers Singingi Hilir District with a coefficient of determination or R-Square of 0.301 or $30.1 \%$, meaning that pedagogical competence and work environment have an influenced on performance of $30.1 \%$.

Kata kunci:

Kompetensi Pedagogik Lingkungan Kerja Kinerja Guru

\begin{abstract}
Abstrak
Penelitian ini dilakukan untuk mengetahui pengaruh kompetensi pedagogik dan lingkungan kerja terhadap kinerja guru di Sekolah Dasar Negeri Kabupaten Kuantan Singingi. Metodologi dalam penelitian ini menggunakan pendekatan kuantitatif model analisis jalur (path analysis). Sampel penelitian terdiri dari 103 orang guru di Kabupaten Kuantan Singingi Kecamatan Singingi Hilir. Instrumen penelitian berupa angket tertutup dalam google form berdasarkan skala likert. Pengujian hipotesis didapat dari uji -t dan uji F. Hasil penelitian menunjukkan bahwa:1) kompetensi pedagogik berpengaruh positif dan signifikan terhadap kinerja guru di Kecamatan Singingi Hilir dengan $t_{\text {hitung }}$ sebesar 3.729 lebih besar dari $t_{\text {tabel }}$ sebesar 1.661 , artinya, meningkatkan kompetensi pedagogik guru akan meningkatkan kinerja guru Sekolah Dasar negeri Kecamatan Singingi Hilir. 2) Lingkungan kerja berpengaruh positif dan signifikan terhadap kinerja guru di Sekolah Dasar Negeri Kecamatan Singingi
\end{abstract}

\footnotetext{
${ }^{1}$ State University of Jakarta, Jakarta, Indonesia

Email: superboymarsen@gmail.com

${ }^{2}$ State University of Jakarta, Jakarta, Indonesia

Email: hrsnts@yahoo.com

3 State University of Jakarta, Jakarta, Indonesia

Email: sitirochanahunj@gmail.com
} 
Hilir dengan thitung sebesar 3.480 lebih besar dari tabel sebesar 1.661, dimana baiknya lingkungan kerja akan meningkatkan kinerja guru. 3) kompetensi pedagogik dan lingkungan kerja berpengaruh terhadap kinerja guru Sekolah Dasar Negeri Kecamatan Singingi Hilir dengan nilai koefisien determinasi atau R-Square sebesar 0,301 atau 30,1\%, artinya kompetensi pedagogik dan lingkungan kerja memberikan pengaruh terhadap kinerja sebesar 30,1\%.

\section{INTRODUCTION}

Educator or teacher is an essential element that is very influential in the world of education. The quality of education in Indonesia in the future depends on the quality. Therefore, the teachers' performance dramatically influences the importance of the role of teachers in determining the future of the nation and state. As teaching staff, teachers are determining factors in improving the quality of education at schools. Therefore, educators or teachers must improve their performance in carrying out their duties because education in the future requires teaching skills at schools. Professional teachers can be a breath of fresh air for success in the future world. To improve teacher performance at schools, they need to attend various training and professional education provided by the government. Britt and Jex (2015) performance is the overall behavior of employees who participate in a job. However, this sometimes does not match an accurate definition because employees often perform tasks not related to other tasks assigned by their superiors.

Law No. 14 on Teachers and Lecturers in 2005 stipulates that "teachers are professional educators whose main task is to pass formal education, basic education, and secondary education." Then, Article 20 of the "Teachers Law" stipulates that teachers should continuously improve and develop their academic qualifications and abilities when performing their professional duties. It is in line with the development and development of science and technology. Based on the explanation above, the teacher must keep up with the times by increasing their competencies to become role models for students in school by improving their performance.

According to Ashar et al. (2019), teacher performance is a teacher's ability to account for a student who is guided in carrying out a learning task and improving student learning outcomes. For example, suppose teachers are highly loyal and committed to teaching tasks, mastering and developing learning materials, teaching discipline and other tasks, creativity in teaching implementation, cooperation with all school members, and leadership become the role of students. In that case, teachers' performance will be outstanding, good role models, pleasing personality, honest and objective guidance to students, and responsible for their responsibilities. Another factor that also affects teacher performance is the work environment, which is a condition that affects a person in carrying out tasks, consisting of physical and non-physical environments. The physical environment is all physical forms that are around the place where the employee is on duty.

Meanwhile, the non-physical environment is a situation that occurs concerning work relationships, for example, the attitude of the boss and the attitude of colleagues. In this study, the work environment in question is the atmosphere of the physical and non-physical environment related to the teacher's feelings while carrying out his duties, so that it is felt safe, comfortable, and peaceful in completing work in the environment where the teacher is on duty (Aisah 2019).

Another factor affecting teacher performance is the work environment, namely the conditions that affect a person in carrying out their duties, consisting of the physical and nonphysical environment. The physical environment is all the physical forms around the place where the employee is on duty. In comparison, the non-physical environment is related to work relations, such as superiors' and friends' attitudes at work. While according to Robbins \& Judge (2017), the work environment exists in the workplace, namely the diversity of tasks and the level of autonomy, job demands, and requirements needed to express the emotions of workers.

Based on data from the center for education and culture data and Statistics, it is known that from the Kuantan Singingi regional education data, there are 249 Education Units for Elementary School. The number of teachers is 2,852 , with 1,907 classrooms that must accommodate 38,686 students, 142 educational staff members, and many study groups $-1,891$ at the Elementary School 
education level. The levels of education in the Kuantan Singingi area on an elementary school, high school and vocational high school, has a good education ratio of 1:1. It indicates one classroom is only filled by 1 study group or about 20 students. Meanwhile, for the ratio of education between teachers and students, the highest ratio is obtained at elementary school education. The education ratio is 1:14, more significant than junior high school, senior high school, and vocational high school. Then the education ratio data regarding the comparative study group with students is at the level of education in Kuantan Singingi, at the Elementary School level, where the education ratio is good, namely 1:20 where one study group is filled with only 20 students in the classroom.

Furthermore, based on previous research results, it showed a positive influence between pedagogical competence variables on performance. According to the research results by Rohman (2020) showing the influence of pedagogic competence variables on teacher performance, the results obtained were R Square $=0.5112$ or $51.12 \%$. It means that the pedagogical competence variable affects teacher performance by $5 \mathbf{1 . 1 2} \%$. The results of other research also show a similar thing, conducted by Sappaile (2017) revealed that pedagogical competence has a positive direct effect on teacher assessment performance. This assessment's findings mean that teachers' performance or performance of assessments conducted by teachers was primarily determined by competence. Pedagogic of the teacher shows an influence between the researchers' variables, namely the influence between competence and work environment on teacher performance. It is under the theory according to Mulyasa (2012). Teaching ability is the ability to manage students' learning, including understanding students, designing and implementing learning, and evaluating results. Learn and develop students to realize the various potentials they have.

The difference between this research and previous research is that researchers focus more on the pedagogic competence of teachers in public elementary schools at Kuantan Singingi. At the same time, other competencies, professional, personality, and social competencies, are not the subject of research, while the work environment variable is an independent variable between the effects of each variable. It is focused on the performance of teachers in school. The research was conducted to show that pedagogical competence and work environment affect teacher performance based on the findings and facts. The results of this study were expected to be useful in understanding what needs to be prepared in managing and preventing teachers. Start from being unprepared in teaching activities in the classroom, a comfortable and conducive environment to support teacher performance improvement because teachers' existence is essential in the sustainability of education in Indonesia.

\section{METHOD}

This study uses an approach quantitative with a path analysis model. The research sample was obtained using the Slovin formula with an error rate of 5\% Sugiyono (2017). The research sample was 103 elementary school teachers in Singingi Hilir District, Regency Kuantan Singingi, with a proportional random sampling technique. The instrument that was distributed to each respondent had previously been tested with validity and reliability using Microsoft excel in calculations. This research was conducted by distributing a closed questionnaire containing statements and alternative answers in the google form application. The questionnaire consisted of 40 statements about the independent variables, namely 40 statements of pedagogical competence and 40 statements of work environment variables, while the dependent variable was 40 statements of teacher performance. So, there were 120 statements on the questionnaire. This study used a path analysis model. It means that several prerequisite tests for analysis include normality test, significance test, linearity test, multicollinearity test, heteroscedasticity test, correlation coefficient test, and t-test. The model is an analysis path used to determine variables X1 and X2 on the Y test variable Sugiyono (2017). The hypothesis was carried out by using the t-test and F-test to determine the effect between variables partially or simultaneously. This model would also be used for the coefficient of determination because this value showed how much influence the independent variable has on the dependent variable. The application used to perform statistical calculations in 
this study was SPSS version 26.

The hypothesis in this study was as follows: (1) pedagogical competence has a positive and significant effect on the performance of teachers at the Singingi Hilir District Elementary School; (2) The work environment has a positive and significant effect on the performance of teachers at the Singingi Hilir Public Elementary School; (3) Pedagogic Competence and Work Environment simultaneously and significantly influence the performance of elementary school teachers in Singingi Hilir District, Kuantan Singingi Regency.

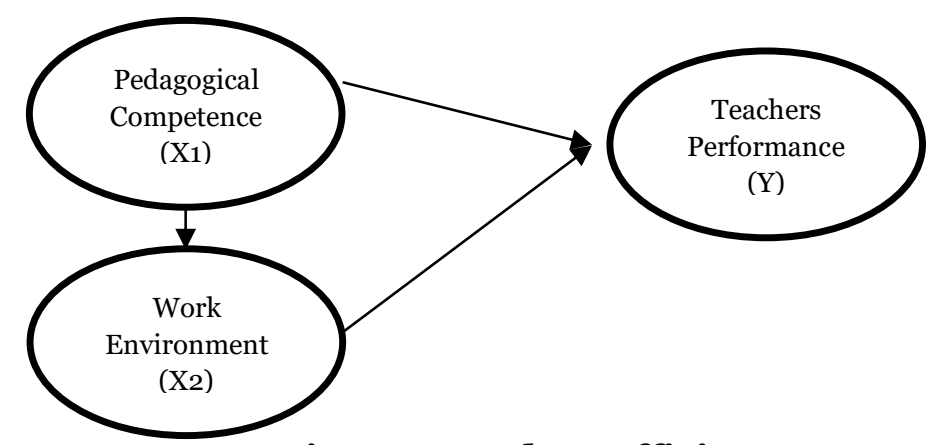

Figure 1. Path Coefficient Test Model

\section{FINDINGS AND DISCUSSION}

\section{Analysis Of Prerequisite Test}

(1) Normality Test

A normality test is a test that is carried out to assess the distribution of data in a group of data or variables, whether the distribution of the data is normally distributed or not. By testing normality using the Liliefors formula and using Microsoft Excel in its calculations. Based on the results of data processing carried out and sourced from research data, it could be seen that $\mid \mathrm{F}$ (Zi) - S (Zi) | The maximum inferred by Lcount for the three regression estimation errors was smaller than the L-table value, the rejection limit Ho listed in the Liliefors table at $\alpha=0.05$ and $\mathrm{n}>30$ is $(0.886) / \sqrt{ } \mathrm{n}$.

Tabel 1. Normality Test Liliefors

\begin{tabular}{llll}
\hline \multicolumn{1}{c}{ Variable } & Lcount & Ltable & Result \\
\hline $\mathrm{X} 1$ on $\mathrm{Y}$ & 0,077 & 0,087 & Normal \\
$\mathrm{X} 2$ on $\mathrm{Y}$ & 0,070 & 0,087 & Normal \\
$\mathrm{X} 2$ on $\mathrm{X} 1$ & 0,047 & 0,087 & Normal \\
\hline \hline
\end{tabular}

Based on the calculation, it is obtained that Lcount $\mathrm{X} 1$ against $\mathrm{Y}$ is $0.077, \mathrm{X} 2$ against $\mathrm{Y}$ is 0.070 , and $\mathrm{X} 2$ against $\mathrm{X} 1$ is 0.047. This value is smaller than the value of Ltable $(\mathrm{n}=103 ; \alpha=0.05)$ of 0.087 . Seeing that the Lcount value is smaller than Ltable, the data distribution of each variable will form a normal curve. Table 1 demonstrates that the variable $\mathrm{X} 1$ on $\mathrm{Y}$ gets the Lcount of 0.077 , which is smaller than the Ltable of 0.087 , meaning that the data is normally distributed, the X2 variable on $\mathrm{Y}$ gets the Lcount of 0.070 , which is smaller than the Ltable of 0.087 , meaning that the data is normally distributed. The $\mathrm{X} 2$ variable on $\mathrm{X} 1$ gets Lcount is 0.047 and Ltable is 0.087 , meaning that the data is normally distributed.

(2) Test of Significance and Linearity

Significance is a test to prove that there is a significant relationship between the independent variable and the dependent variable in the study. In this study, two independent variables were pedagogical competence and work environment and one dependent variable: performance. This significant test was calculated using SPSS version 26, and the following results were obtained: 
Tabel 2. Linearity Test: Pedagogical Competence on Teacher performance

\begin{tabular}{|c|c|c|c|c|c|c|c|}
\hline & & & $\begin{array}{c}\text { Sum of } \\
\text { Squares }\end{array}$ & $\mathrm{df}$ & $\begin{array}{c}\text { Mean } \\
\text { Square }\end{array}$ & $\mathrm{F}$ & Sig. \\
\hline Teacher & Between & (Combined) & 30512.10 & 48 & 635.669 & 1.62 & .043 \\
\hline Performance & Groups & & 7 & & & O & \\
\hline$\left(\mathrm{X}_{3}\right) *$ & & Linearity & 11210.96 & 1 & 11210.9 & 28.5 & .000 \\
\hline Pedagogical & & & $\mathrm{O}$ & & 60 & 79 & \\
\hline Competence & & Deviation from & 19301.14 & 47 & 410.663 & 1.04 & .433 \\
\hline$(\mathrm{X} 1)$ & & Linearity & 6 & & & 7 & \\
\hline & \multirow{2}{*}{\multicolumn{2}{|c|}{ Within Groups }} & 21183.0 & 54 & 392.278 & & \\
\hline & & & OO & & & & \\
\hline & \multirow{2}{*}{\multicolumn{2}{|c|}{ Total }} & 51695.10 & 102 & & & \\
\hline & & & 7 & & & & \\
\hline
\end{tabular}

From the above results, the significance value of competency variables pedagogic (X1) to the performance variable $(\mathrm{Y})$ is 0.433 . Because $0.433>0.05$, it can be concluded that there is a linear relationship between variables pedagogical competence on teacher performance.

Tabel 3. Linearity Test: Work Environment on Teacher performance

\begin{tabular}{|c|c|c|c|c|c|c|c|}
\hline & & & $\begin{array}{c}\text { Sum of } \\
\text { Squares }\end{array}$ & $\mathrm{df}$ & $\begin{array}{c}\text { Mean } \\
\text { Square }\end{array}$ & $\mathrm{F}$ & Sig. \\
\hline \multirow{5}{*}{$\begin{array}{l}\text { Teacher } \\
\text { Performance } \\
\left(\mathrm{X}_{3}\right)^{*} \text { Work } \\
\text { Environment } \\
\text { (X2) }\end{array}$} & \multirow{3}{*}{$\begin{array}{l}\text { Between } \\
\text { Groups }\end{array}$} & (Combined) & 23400.462 & 38 & 615.802 & 1.393 & .120 \\
\hline & & Linearity & 10563.359 & 1 & 10563.3 & 23.8 & .00 \\
\hline & & $\begin{array}{l}\text { Deviation } \\
\text { from } \\
\text { Linearity }\end{array}$ & 12837.103 & 37 & $\begin{array}{r}59 \\
346.949\end{array}$ & $\begin{array}{r}93 \\
.785\end{array}$ & $\begin{array}{r}0 \\
.785\end{array}$ \\
\hline & \multicolumn{2}{|c|}{ Within Groups } & 28294.645 & 64 & 442.104 & & \\
\hline & \multicolumn{2}{|l|}{ Total } & 51695.107 & 102 & & & \\
\hline
\end{tabular}

From the above results, the significance value of the work environment variable (X2) on the performance variable $(\mathrm{Y})$ is 0.785 . Because $0.433>0.05$, it can be concluded that there is a linear relationship between work environment on teacher performance.

(3) Correlations Test

Tabel 4. Correlations Test

\begin{tabular}{cccc}
\hline \hline Matriks & \multicolumn{3}{c}{ Koefesien Korelasi } \\
& $\mathrm{X}_{3}$ & $\mathrm{X}_{1}$ & $\mathrm{X}_{2}$ \\
\hline $\mathrm{X}_{3}$ & 1 & 0,466 & 0,452 \\
$\mathrm{X}_{1}$ & 0,466 & 1 & 0,398 \\
$\mathrm{X}_{2}$ & 0,452 & 0,398 & 1 \\
\hline
\end{tabular}

The table above shows that the correlation between the work environment and the pedagogic competence $\mathrm{r} 12$ is 0.398 . Likewise, the correlation between pedagogic competence and r13 performance is 0.466 . Finally, the correlation between the work environment and teacher performance $\mathrm{r} 23$ is 0.452 .

4) Multicollinearity Test

Multicollinearity is used to determine whether there is a correlation between independent variables. A good regression model is a model that does not have symptoms multicollinearity with a value tolerance $>0.10$ and a VIF value $<10.00$. After the multicollinearity test was carried out using SPSS version 26 , the following results were obtained: 
Tabel 5. Multicollinearity Test

\begin{tabular}{|c|c|c|c|c|c|c|c|c|}
\hline \multirow{2}{*}{\multicolumn{2}{|c|}{ Model }} & \multicolumn{2}{|c|}{$\begin{array}{l}\text { Unstandardized } \\
\text { Coefficients }\end{array}$} & \multirow{2}{*}{$\begin{array}{c}\text { Standardized } \\
\text { Coefficients } \\
\text { Beta }\end{array}$} & \multirow[t]{2}{*}{$\mathrm{t}$} & \multirow[t]{2}{*}{ Sig. } & \multicolumn{2}{|c|}{$\begin{array}{l}\text { Collinearity } \\
\text { Statistics }\end{array}$} \\
\hline & & B & Std. Error & & & & Tolerance & VIF \\
\hline \multirow[t]{3}{*}{1} & (Constant) & 42.766 & 16.683 & & 2.563 & .012 & & \\
\hline & $\begin{array}{l}\text { Pedagocical } \\
\text { Competence (X1) }\end{array}$ & .354 & .095 & .340 & 3.729 & .000 & .842 & 1.188 \\
\hline & $\begin{array}{l}\text { Work } \\
\text { Environment(X2) }\end{array}$ & .357 & .102 & .317 & $\begin{array}{r}3.48 \\
0 \\
\end{array}$ & .001 & .842 & 1.188 \\
\hline
\end{tabular}

From the results of the table above, it can be seen that the tolerance value is $0.842>0.10$. It means that there are no symptoms of multicollinearity in this study. In addition, decision-making can also be done by looking at the VIF. Because the VIF value is $1.188<10.00$, it can be concluded that there are no symptoms of multicollinearity in this research model.

(4) Heteroscedasticity Test

Heteroscedasticity is used to determine whether a regression model has a variant value fixed residual from one observation to another. The heteroscedasticity test in this study uses the Rank Spearman test based on decision-making if the value is significant or sig. (2-tailed) is greater than 0.05. So, there is no problem with heteroscedasticity. After calculating using SPSS version 26, the following results were obtained:

Tabel 5. Heteroscedasticity Test

\begin{tabular}{|c|c|c|c|c|c|}
\hline \multirow[t]{2}{*}{ Model } & \multicolumn{2}{|c|}{$\begin{array}{c}\text { Unstandardized } \\
\text { Coefficients }\end{array}$} & \multirow{2}{*}{$\begin{array}{c}\text { Standardized } \\
\text { Coefficients }\end{array}$} & \multirow[t]{2}{*}{$\mathrm{t}$} & \multirow[t]{2}{*}{ Sig. } \\
\hline & B & Std. Error & & & \\
\hline 1 (Constant) & -.222 & $\begin{array}{r}9.8 \\
62\end{array}$ & & -.022 & .982 \\
\hline $\begin{array}{l}\text { Pedagogical } \\
\text { Competence(X1) }\end{array}$ & .069 & $\begin{array}{r}.05 \\
6\end{array}$ & .133 & 1.234 & .220 \\
\hline $\begin{array}{l}\text { Work Environment } \\
\text { (X2) }\end{array}$ & .030 & $\begin{array}{r}.06 \\
1\end{array}$ & .054 & .499 & .619 \\
\hline
\end{tabular}

Based on the table above, it can be seen that the Sig. (2-tailed) value for pedagogic competence is 0.220 , which is more significant ( $>$ ) than 0.05. Then, the Sig. (2-tailed) for the work environment is 0.619 , which is greater $(>)$ than 0.05 . Because the two significance values obtained are more significant than 0.05 , it can be concluded that there is no heteroscedasticity problem in this regression model. It means that the regression model in this study has a fixed residual variant value from one observation to another.

\section{Path Analysis}

After using SPSS version 26 to search for multiple linear regression models for this study, the following results were obtained:

Tabel 6. Multiple Linear Regression Analysis

\begin{tabular}{lc}
\hline \hline Variable & Regression Coefficient \\
\hline Constant & 42.766 \\
Pedagogical Competence (X1) & 0,354 \\
Work Environment (X2) & 0,357 \\
\hline \hline
\end{tabular}

From these results it can be concluded that the regression equation model in this study is: $\mathrm{Y}=$ $42,766+0.354+0.357$. Then also has the value of the coefficient of determination from this equation: 
Table 7. T-Test

\begin{tabular}{|c|c|c|c|c|c|c|}
\hline & \multirow[t]{2}{*}{ Model } & \multicolumn{2}{|c|}{$\begin{array}{l}\text { Unstandardized } \\
\text { Coefficients }\end{array}$} & \multirow{2}{*}{$\begin{array}{c}\begin{array}{c}\text { Standardize } \\
\text { d } \\
\text { Coefficients }\end{array} \\
\text { Beta }\end{array}$} & \multirow[t]{2}{*}{$\mathrm{t}$} & \multirow[t]{2}{*}{ Sig. } \\
\hline & & B & Std. Error & & & \\
\hline \multirow[t]{3}{*}{1} & (Constant) & 42.766 & 16.683 & & 2.563 & .012 \\
\hline & $\begin{array}{l}\text { Pedagogical } \\
\text { Competence (X1) }\end{array}$ & .354 & .095 & .340 & 3.729 & .000 \\
\hline & $\begin{array}{l}\text { Work } \\
\text { Environment (X2) }\end{array}$ & .357 & .102 & .317 & 3.480 & .001 \\
\hline
\end{tabular}

From the results obtained above, pedagogic competence (X1) and work environment (X2) affect teacher performance partially. This is evident from the significant value of each independent variable. The significance of the pedagogic competence variable is 0.000 which is smaller $(<)$ than 0.05. In addition, the t-count value for the pedagogic competency variable is 3,729 greater $(>)$ than t-table 1.66. It can be concluded that pedagogic competence (X1) affects teacher performance. the work environment variable (X2) with a value of 0.001 is also smaller $(<)$ than 0.05 . The tcount value of work environment variable is 3,480 greater $(>)$ than t table 1.66. This shows a positive influence between work environment and performance. So the direct effet (Path Coefficients) Pedagogical competence $(\mathrm{X} 1) \quad(\mathrm{p} 31) 2=(0,340) 2=0,115$, Work Environment $(\mathrm{X} 2)(\mathrm{p} 32) 2=(0,317) 2=0,100$ while the effect is through the correlation of other exogenous variables: Pedagogical competence on teachers performance: $(0,340) \times(0,317) \times(0,398)=0,043$, work environment on teacher performance: $(0,317) \times(0,340) \times(0,389)=0,043$. The total effect of exogenous variables with endogenous variables: pedagogical competence on teacher performance: $(0,115)+(0,043)=0,158$, work environment on teacher performance: $(0,100) x(0,043)=0,143$.

Tabel 8. Coefficient of Determination Value

\begin{tabular}{cccccc}
\hline \hline $\mathrm{R}$ & R Square & $\begin{array}{l}\text { Adjusted R } \\
\text { Square }\end{array}$ & $\begin{array}{l}\text { Std.error of } \\
\text { estimate }\end{array}$ & the \\
\hline 0,549 & 0,301 & 0,287 & 19.00284 & \\
\hline
\end{tabular}

From the results above, it can be seen that the coefficient of determination of this regression equation. The coefficient value shows how much influence the independent variable has on the dependent variable simultaneously. From the results obtained, it is known that the coefficient of determination is 0.301 or $30.1 \%$. This means that the pedagogic competence variable (X1) and the work environment variable (X2) has a simultaneous effect on the teacher performance variable (Y) by $30.1 \%$. Meanwhile, the other $69.9 \%$ were influenced by other variables which were not researched.

2) F-Test

Table 9. F-Test

\begin{tabular}{lccccc}
\hline \hline Model & $\begin{array}{c}\text { Sum } \\
\text { Square }\end{array}$ & Df & Mean Square & F & Sig \\
\hline Regression & $\begin{array}{c}15584.31 \\
\text { o }\end{array}$ & 2 & 7792.155 & 21.578 & 0,000 \\
\hline Residual & $\begin{array}{c}36110.79 \\
7\end{array}$ & 100 & 361.108 & & \\
\hline Total & $\begin{array}{c}51695.10 \\
7\end{array}$ & 102 & & & \\
\hline
\end{tabular}

From the table above, it can be seen that pedagogic competence and work environment influence teacher performance simultaneously. It can be seen from the significance value (Sig.) Which is equal to 0.000 , which is smaller $(<)$ than 0.05 . In addition, conclusions can be drawn by 
looking at the Fcount value. Fcount value of 21,578 is more excellent ( $>$ ) than Ftable 3.09. From these results, it can be concluded that pedagogic competence and work environment simultaneously affect teacher performance. It can be seen from the significance value of the $\mathrm{F}$ test of 0.000 . This value is smaller $(<)$ than 0.05 , which means a simultaneous influence of pedagogical competence and work environment on teacher performance. The value of Fcount is 21,578 , which is also greater $(>$ ) than Ftable, which is worth 3.09. the effect of these two variables is $30.1 \%$ on teacher performance. It is indicated by the value of $\mathrm{R} 2=0.301$. It can be concluded that pedagogic competence and work environment have a simultaneous and significant effect on the performance of elementary school teachers in Singingi Hilir District, Kuantan Singingi Regency, which means that this research hypothesis was accepted.

The results of this study were in line with several findings of previous studies. First, Supriyono's (2017) research found that teacher performance factors are pedagogical and professional competencies and motivational factors that can affect teacher performance. Namely, the results of this study indicate good results partially and simultaneously. The influence of pedagogic competence is 0.661 , professional competence is 0.447 , and work motivation is 0.581 . These results indicate that there is a partially significant influence on teacher performance. Furthermore, there are significant differences based on teachers' employment status, with government employees status having pedagogical competence, professional and work motivation, and better performance than teachers with status non-civil servants.

Furthermore, Murkatik et al. (2020) found that many factors influence teacher performance in teaching. The factors that influence the teaching performance of teachers studied in this study were teacher pedagogical competencies. The results of this study indicated that the teaching performance of Prabumulih State Junior High School teachers was in the relatively good category competence. Therefore, professional and pedagogical have a very positive effect on teacher performance. Then, (Sutrisno et al., 2020) found a positive effect of teacher competence on job satisfaction and teacher performance at State Junior High School 1 East Cikarang. In her study, Nellitawati (2020) concludes that Nellitawati (2020) has a significant influence of pedagogic competence on performance with 86 vocational school teachers in the City of Padang.

Another study by Sudibjo \& Nasution (2020) found that the factors that influence teacher performance were pedagogical competence factors and work environment and work motivation factors, an organizational culture that can affect teacher performance. The results of this study indicate that the work environment has a positive effect on teacher performance. In this study, the teacher views that the tools or media needed to teach in the classroom are useful in teaching activities in the classroom, so it can be concluded that the provision of tools necessary or media can improve teacher performance. Wilian et al. (2020) state a positive influence of pedagogic competence on academic performance at Nahdlatul Wathan University. Next, Sari (2019) research found a linkage between competence pedagogical and the work environment that affects teachers' performance in the school. However, the work environment dramatically affects the pedagogic competence of teachers in comfort teaching and learning in the classroom, so that it will give good performance results if the working environment is good. Pahrudin et al. (2016) found a positive influence between pedagogic, professional, personality, and social competence variables on learning achievement. Septia et al. (2016) here is a positive influence between pedagogical competence variables on teacher performance.

Based on the research results, the direct influence of the work environment on performance is 0.100. It is in line with the research conducted by Sudibjo \& Nasution (2020), who obtained the results of a direct influence of 0.187 , meaning that the influence that the researchers did was lower than the previous researchers. Meanwhile, for the direct effect of pedagogic competence on performance, the result is 0.340 . This aligns with research conducted by Wilian et al. (2020), with a regression coefficient value of 0.429 . Therefore, this result shows a positive influence between the 
two variables. Furthermore, the total for the effect of all variables based on the coefficient of determination is 0.301 , meaning that this study is only influenced by $30.1 \%$. In comparison, the other $69.9 \%$ is influenced by other variables that the researcher did not examine.

\section{CONCLUSION}

This study shows a positive and significant influence between the variables, both endogenous and erogenous. Therefore, public Elementary Schools at Singingi Hilir District, Kuantan Singingi Regency must pay attention again to the pedagogic competence possessed by teachers when carrying out learning in the classroom. The environment where they carry out activities during school must be considered again both in terms of cleanliness, comfort, lighting, and harmony. Teachers must also independently improve their pedagogical competence or in groups by participating in training and knowledge on improving pedagogic competence from various information sources. In addition, schools must also pay attention to the welfare of teachers to complete various kinds of support facilities learning in class and outside the classroom so that teachers are motivated and can improve their performance even better. This research still has weaknesses in its implementation because it is only limited to using the questionnaire technique on the google form application in the data collection process. Future researchers who will discuss similar matters can take more samples and include other variables not examined in this study.

\section{REFERENCES}

Aisah, I. (2019). Kontribusi kompetensi dan lingkungan kerja terhadap kinerja guru. Jurnal Dialogika Manajemen Dan Administrasi, 1(1), 19-26.

Ashar, K. M., Mujanah, S., \& Murgianto. (2019). Pengaruh Kompetensi, Dukungan Organisasi, Terhadap Kinerja Guru Dengan Motivasi Sebagai Variabel Intervening Pada Yayasan Pendidikan Cendekia Utama Surabaya. 04(01), 1-14.

Britt, T. W., \& Jex, S. M. (2015). Thriving under Stress, harnessing demands in the workplace. Oxford University Press.

Mulyasa. (2012). Standar Kompetensi dan Sertifikasi Guru. Rosda karya.

Murkatik, K., Harapan, E., \& Wardiah, D. (2020). The Influence of Professional and Pedagogic Competence on Teacher' s Performance. Journal of Social Work and Science Educatioan, 1(1), 58-69.

Nellitawati, N. (2020). The influence of teacher pedagogical competence of teachers' work morale. Journal of Counceling and Educational Technology, 3(1), 29-33.

Pahrudin, Martono, T., \& Murtini, W. (2016). The Effect of Pedagogic Competency, Personality, Professional and Social Competency Teacher to Study Achievement of Economic Lesson in State Senior High School of East Lombok District Academic Year 2015/2016. International Conference on Teacher Training and Education, 2(1), 332-345.

Robbins, S. P., \& Judge, T. A. (2017). Organizational Behavior (S. Wall (ed.); Seventeent). Pearson.

Rohman, H. (2020). Pengaruh kompetensi guru terhadap kinerja guru. Jurnal Madinasika Manajemen Dan Keguruan, 1(2), 92-102.

Sappaile, N. (2017). Pengaruh Kompetensi Pedagogik, Kompetensi Profesional , dan Sikap Profesi Guru Tehadap Kinerja Penilaian Guru di Sekolah Dasar. Jurnal Teknoloagi Pendidikan, 19(1), 47-58.

Sari, F. M. (2019). Pengaruh Kompetensi Dan Lingkungan Kerja Terhadap Kepuasan Kerja Dan Kinerja Guru Di Sd Negeri Kecamatan Gondang Mojokerto. Jurnal Ilmu Ekonomi \& Manajemen, 1(1), 19-26.

Septia, K., Ningrum, C., Studi, P., Ekonomi, P., Ekonomi, F., \& Ganesha, U. P. (2016). Pengaruh Kompetensi Guru Terhadap Kinerja Guru Smp Negeri 6 Singaraja Komang Septia Cahya Ningrum. Jurnal Program Studi Pendidikan Ekonomi (JPPE), 7(2).

Sudibjo, N., \& Nasution, R. A. (2020). Work Environment, Work Motivation, and Organizational Culture in Influencing Teachers' Performance. 53(2017), 276-286.

Sugiyono. (2017). Metode Penelitian Kuantatif, Kualitatif, dan R\&D.

Supriyono, A. (2017). The Influence Of Pedagogic, Professional Competency, And Work Motivation Onteacher Performance Of. Jurnal Pendidikan, 18(2), 1-12.

Sutrisno, N., Isyanto, H. P., \& Hasbullah, R. (2020). Influence of Teacher Competence, Motivation and Job Satisfaction on Teacher's Performance SMP Negeri 1 Cikarang Bekasi Regency East 
5 Influence of Teacher Competence, Motivation and Job Satisfaction o $n$ Teacher' $s$ Performance SMP Negeri 1 Cikarang Be. March 2017. https://doi.org/10.47312/ambr.v1io1.31 Wilian, S., Studi, P., Administrasi, M., Mataram, U., Mataram, N. W., Profesional, K., Dosen, K. A., \& Murkatik, M. (2020). Pengaruh Kompetensi Pedagogik Terhadap Kinerja Akademik Dosen. Jurnal Ilmu Sosial Dan Pendidikan, 4(4), 583-589. 